\title{
墓石の転倒調査から推定した兵庫県南部地震の際の 神戸市およびその周辺での震度分布 \\ ISOSEISMAL MAP OF THE HYOGO-KEN NANBU EARTHQUAKE IN AND AROUND KOBE CITY ESTIMATED FROM OVERTURNING OF TOMBSTONES
}

\author{
翠川三郎*, 藤 本一雄** \\ Saburoh MIDORIKAWA and Kazuo FUJIMOTO
}

\begin{abstract}
Field observations on overturning of tombstones during the Hyogo-ken Nanbu Earthquake was performed in and around Kobe City. The relation of geomorphological condition and geomorphometric measures (elevation and gradient) with the overturning rate of tombstones was examined quantitatively, and the empirical equations between the gradient and the overturning rate were proposed for each geomorphological condition. The distribution of the overturning rate in the disastrous area was estimated by the equations together with the geomorphological map. The distribution of the overturning rate was transformed into the distribution of peak ground velocity by using the relation derived from the observed peak ground velocity and the overturning rate of tombstones.
\end{abstract}

Keywords: isoseismal map, the Hyogo-ken Nanbu Earthquake, overturning of tombstone, geomorphological condition, geomorphometry, peak ground velocity

震度分布図, 兵庫県南部地震, 墓石の転倒, 地形条件, 地形計測, 最大地動速度

1.はじめに

1995年兵庫県南部地震は阪神・淡路地域に大きな被害 をもたらした。特に「震災の帯」と呼ばれる帯状の地域で は甚大な被害が生じた。震災の帯を含む被災地域での地 震動強さの分布を明らかにできれば，震源域およびその 周辺での地震動強さについての知見を増やせるととも に, 被災地域での構造物の被害を評価する上でも有用と なろう。

今回の地震では各機関により多数の強震記録が得ら れたが，被害の甚大な地域では強震記録はほとんど得ら れていない。したがって, 計器観測の結果のみから被災 地域での地震動強さの分布を知ることは非常に困難で ある。計器観測を補うものとして，以前より墓石の転倒 調査が行われ，各地での地震動強さが推定されてきた”。 しかし，神戸市のように都市化の進んだ地域では都市中 心部に点在していた墓地は都市周辺部の大規模な共同 墓地に集約されつつあり，都市中心部での調查地点の数
は限られることになる。このような限られた地点でのデ 一夕の空間的補間のみから震度分布のような面的な広 がりを持ったデータに変換することには困難が伴う。

従来より地震動の特性は地盤の影響を大きく受ける ことが指摘され，これを評価する指標として地盤分類が 用いられてきた2)。そこで, 各地盤分類毎に墓石の転倒 状況が整理できれば，各地盤分類での結果を同一の地盤 分類を持つ地盤に適用して, 墓石の転倒状況の面的分布 を推定することができ，さらには震度分布を推定するこ とが可能であろう。

本研究では, 神戸市およびその周辺での地形分類デー 夕を作成し, 地形条件と墓石の転倒率との関保を定量的 に評価した。さらにこれらの関係にもとづいて，被災 地域での墓石の転倒率の分布を求め，これを最大速度分 布に変換して, 神戸市での震度分布を推定することを試 みた。
* 東京工業大学大学院総合理工学研究科 人間環境システム専攻 教授・工博

** 東京工業大学大学院総合理工学研究科 人間環境システム専攻 大学院生・修士 (工学)
Prof., Dept. of Built Environment, Interdisciplinary Graduate School of Science and Engineering, Tokyo Institute of Technology, Dr. Eng. Graduate Student, Dept. of Built Environment, Interdisciplinary Graduate School of Science and Engineering, Tokyo Institute of Technology, M. Eng. 


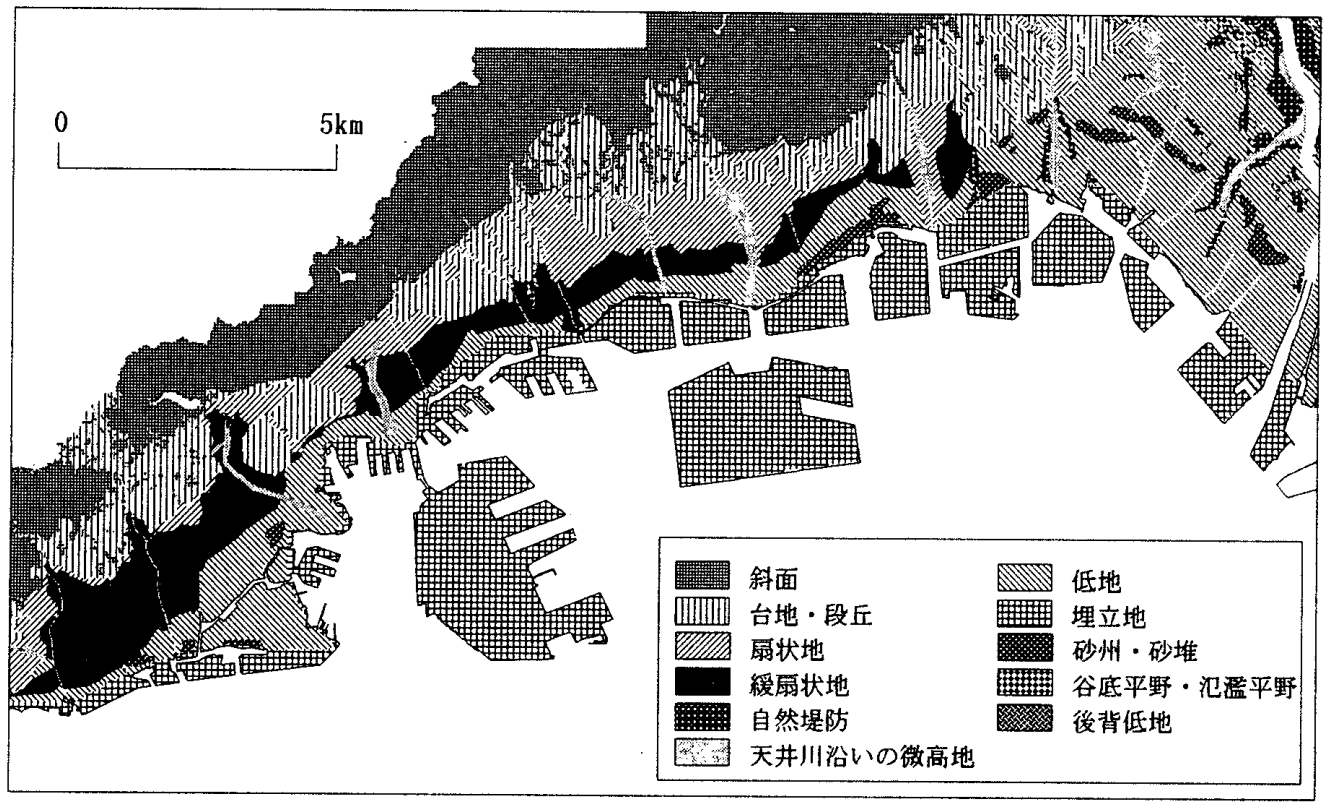

図 1 地形分類図

\section{2. 地形データの作成}

\section{1 地盤特性と地形分類}

地盤特性を評価するための地盤分類として，表層地質， 地盤種別，地形分類などが用いられる場合が多い。これ らのうちでは，地形分類がより有効であることが指摘さ れている3゙。今回の地震でも特定の地形条件で被害が集 中していることが指摘されている(4)-6)。

しかし，同じ地形条件であっても地盤構成に変化がみ られ地盤特性にばらつきがみられる場合がある。例えば， 同じ扇状地であっても，勾配が急で流速の大きい河川上 流部では比較的粗粒の物質が堆積し，勾配が緩やかで流 速の小さい下流部では細粒物質が堆積するため, 勾配の 大小によって地盤構成が変化していることが指摘され ているク。また，標高により河川の上流下流を表現する ことができると考えれば，標高が高いところには粒径の 大きい物質が堆積し，標高が低いところには粒径の小さ い物質が堆積するものと考えられる。

したがって，同一地形条件であっても，標高や勾配の 大小により地盤構成が変化していることが考えられ，同 一地形条件での地盤構成の相違を, 標高あるいは勾配と いった地形計測値を用いることによりある程度表現で きるものと考えられる。そこで, 本研究では, 地盤分類 として地形条件を用い,さらに標高や勾配の地形計測值 も考慮することとした。

\section{2 地形分類データの作成}

地形分類データの作成には, 土地条件図, 明治時代の 地形図，現行の地形図を使用した。土地条件図として国 土地理院による縮尺 2 万千 5 分の 1 の地形分類図を用い, これに記載されている地形分類を数值化した後, 斜面, 台地 - 段丘, 扇状地; 緩扇状地, 低地, 自然堤防, 天井
川沿いの微高地, 砂州・砂堆, 谷底平野 - 氾濫平野, 後 背低地の地形条件にまとめなおした。さらに，低地につ いては，明治10年代の地形図 ${ }^{8}$ に示されている海岸線よ りも海側の地域を埋立地とし, 最終的に11種類の地形条 件に分類した．現在の海岸線については，地震後に国土 地理院から刊行された縮尺2万5千分の1の地形図(緊急修 正版)から読み取りを行った。

これら数值化された地形分類データはベクター(ポリ ゴン)データであるが，解析作業を容易にするために $50 \mathrm{~m}$ メッシュのラスターデータへと変換した。その際，1つ のメッシュ内に複数の地形条件が存在する場合には, メ ッシュ内で占有面積が最も大きい地形条件がそのメッ シュを代表するものとした。なお，本研究で対象とした 地域忙, 経度方向で $135^{\circ} 7.5^{\prime} \sim 135^{\circ} 22.5^{\prime}$, 緯度方向で $34^{\circ}$ $35^{\prime} \sim 34^{\circ} 45^{\prime}$ の範围である。数值化された地形分類図を図 1 に示す。

\section{3 数値標高モデルによる地形計測值}

数値標高モデルは，等間隔の格子点での標高值を数值 化したもので，本研究では国土地理院による「数值地図 $50 \mathrm{~m}$ メシュ（標高）」を用いた。これは，縮尺2万5千分 の1地形図を経度方向および緯度方向に200等分して得 られる各メッシュの中心点の標高值がファイル化され たものである。メッシュの大きさは約 $50 \mathrm{~m}$ となり，標高 值は $0.1 \mathrm{~m}$ 単位で表現されている。

この数值標高モデルを用いて，勾配を計算した”。勾 配の值 $(\mathrm{gr} a d)$ は, 緯度方向と経度方向の勾配を合成した (1)式により求めた。なお, (1)式において, $u(m, n)$ は点 $(m, n)$ の標高である。 $\Delta x$ は格子間隔 $(50 \mathrm{~m})$ である。 


$$
\operatorname{grad}=\sqrt{\{\imath(m+1, n)-\imath(m, n)\}^{2}+\{\imath(m, n+1)-\imath(m, n)\}^{2}} / \Delta x
$$

以上より, 本研究で使用する数値データの各メッシュ には，地形条件，標高，勾配といった属性が与えられて いることになる。

\section{表 1 墓石の転倒率}

\begin{tabular}{|c|c|c|c|}
\hline 地点名（住 所） & $\begin{array}{c}\text { 転到率 } \\
(\%)\end{array}$ & 墓石数 & $\begin{array}{l}\overline{7}^{\prime}-4 の \\
\text { 信頼度 }\end{array}$ \\
\hline 服部霊園（豊中市広田町） & 20 & 10000 以上 & $\mathrm{C}$ \\
\hline 瑞輸寺 (兽中市中婪塚) & 10 & 30 & $\bar{B}$ \\
\hline 浄行寺 (豊中市走井) & 5 & 133 & $B$ \\
\hline 本泉寺(伊丹市伊丹) & 25 & 約 250 & $\bar{B}$ \\
\hline 本興寺 (尼崎市寺町) & 4 & 約 240 & B \\
\hline 全自寺 (尼崎市寺町) & 3 & 324 & $\overline{\mathrm{B}}$ \\
\hline 菎昜寺 (伊丹南寺本) & 80 & 約 300 & B \\
\hline 上田墓地（西宮市上田果） & 10 & 約300 & $\bar{B}$ \\
\hline 今荲町菆地 (宝塚市今里) & 97 & 274 & $\mathrm{~B}$ \\
\hline 極楽寺（西宮市宜林町） & 90 & 約50 & $\mathrm{B}$ \\
\hline 鳴尾墓地 (西宮市上鳴尾町) & 40 & 約1000 & B \\
\hline 中!寺 (宝榢市中山町) & 65 & 約 1000 & $\bar{B}$ \\
\hline 本妙寺 (宝榢市小浜) & 6 & 料 100 & B \\
\hline 貝之助墓地（西宮市段上町） & 60 & 粎 600 & $\mathrm{~B}$ \\
\hline 法性寺(宝塚市伊子志) & 0 & 䄪70 & $\bar{C}$ \\
\hline 浄䫛寺 (西宮市津門呉羽町) & 85 & 料350 & $\bar{B}$ \\
\hline 平林寺(宝榢市社町) & 30 & 料 400 & $\overline{\mathrm{B}}$ \\
\hline 曹乗寺 (西宮市広田町) & 90 & 料 150 & $\mathrm{~B}$ \\
\hline 海清寺（西宮市六湛寺町） & 65 & 34 & $\bar{A}$ \\
\hline 满池谷墓地 (西宫市奥皇) & 60 & 约 10000 & $A$ \\
\hline 西安寺(西宮市産所町) & 90 & 料 400 & $\bar{C}$ \\
\hline 森基墓地 (西宮市鄉免町) & 90 & 粎500 & A \\
\hline 䄨山墓園（西宮市甲陽園目神山町） & 30 & 約 4000 & B \\
\hline 親王寺 (芦屋市打出町) & 98 & 构 40 & $\mathrm{~B}$ \\
\hline 芦屋宋霊園 (芦屋宋别容) & 80 & 7000 前偻 & $\bar{B}$ \\
\hline$=$ 三条墓地 (芦屋市三条町) & 80 & 䄪 150 & $\mathrm{C}$ \\
\hline 本庄墓地（神户市東灌区深江北町） & 95 & $1500-2000$ & $\overline{\mathrm{B}}$ \\
\hline 茜青杰墓地（神吉市東濰区本山南町） & 99 & 料 130 & $\bar{B}$ \\
\hline 安念寺田中悬地（神戸市果稚区甲南町） & 95 & 約 250 & $\bar{A}$ \\
\hline 魚崎墓園(神戸市東濰区魚椅北町) & 90 & 約1200 & A \\
\hline 鬼塚墓園（神戸市東灌区住吉東町） & 98 & 300 & A \\
\hline 野寄墓地 (神戸市東濰区西成本) & 70 & 䄪300 & $\bar{B}$ \\
\hline 光明寺墓地 (神户市東㠜区岡本) & 40 & 約200 & $\overline{\mathrm{C}}$ \\
\hline 住吉霊園 (神戸市東㠜区住吉台) & 30 & 粎3000 & $\mathrm{C}$ \\
\hline 中勝寺 (神戸市東知区御影町群家) & 90 & 刋 250 & B \\
\hline 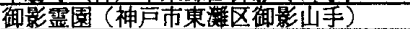 & 5 & 构1500 & $\bar{A}$ \\
\hline 石屋墓園（神戸市東知区御影西平野） & 85 & 粎 1500 & $\mathrm{~B}$ \\
\hline 善光寺 (神户市雉区桜 $ヶ$ 兵町) & 50 & 36 & $\overline{\mathrm{B}}$ \\
\hline 高羽墓地（神戸市灌区揆ヶ丘町） & 70 & 約 200 & A \\
\hline 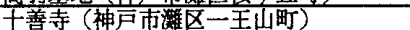 & 80 & 新90 & $\mathrm{C}$ \\
\hline 福正寺墓地（神戸市湤区篗原南町） & 90 & 約 250 & $\mathrm{C}$ \\
\hline 慶光寺（神巨市灌区篗原中町) & 85 & 粷60 & $\mathrm{B}$ \\
\hline 善立寺（神可市灘区大石北町） & 98 & 約 300 & $\mathrm{~B}$ \\
\hline 样龍寺 (神戸市灌区徐原北町) & 2 & 䄪100 & $\bar{B}$ \\
\hline 長峰墓地（神戸市灌区大石） & 5 & 数干 & $\mathrm{B}$ \\
\hline 春日野墓地（神戸市中央区中島通） & 2 & 3000 前後 & $\bar{B}$ \\
\hline 追谷墓園（神戸市中央区堂徳山） & 2 & 䄪3500 & $\bar{A}$ \\
\hline 福徳寺（神市市中央区花幔町） & 80 & 約40 & B \\
\hline 安盦寺（神巨市中央区楠町） & 60 & 粎300 & $\mathrm{B}$ \\
\hline 阿弥陀寺 (秆市市兵庫区中之島) & 55 & 740 & $\mathrm{~B}$ \\
\hline 藤之寺（神户市兵庫区兵庫町） & 90 & 料 200 & $\overline{\mathrm{B}}$ \\
\hline 馬垣墓地 (神巨市兵庫区馬場町) & 80 & 約 400 & A \\
\hline 金光寺 (神户市兵庫区西仲町) & 75 & 約 150 & $\bar{B}$ \\
\hline 真北寺（神戸市兵庫区松原通） & 75 & $700-800$ & $\mathrm{~B}$ \\
\hline 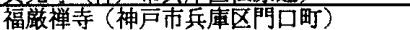 & 80 & 約 150 & $\bar{B}$ \\
\hline 宝地院（神户市兵庫区荒田町） & 50 & 䄪80 & B \\
\hline 福昌寺 (神戸市兵庫区羽坂通) & 95 & 料350 & $\bar{A}$ \\
\hline 願成寺（神户市兵庫区松本通） & 99 & 䄪 350 & B \\
\hline 高松䔔地（神戸芇兵庫区高松町） & 30 & 的 400 & $\bar{A}$ \\
\hline 石井墓地（神戸市兵庫区天王町） & 0 & 料500 & B \\
\hline 長田墓地（神户市長田区西山町） & 70 & $400-500$ & B \\
\hline 㡍泉寺（神声市長田区明泉寺町） & 10 & 粎 110 & $\mathrm{C}$ \\
\hline 宝灌寺（神戸市長田区東肩池町） & 98 & 約 90 & $\mathrm{~B}$ \\
\hline 㦂福寺（神戸市長田区大谷町） & 40 & 料 300 & $\bar{C}$ \\
\hline 原取墓地（神戸市須磨区行平町） & 95 & 料 400 & A \\
\hline 䡩越墓園（神户市北区崮町） & 3 & 約 47000 & $\bar{A}$ \\
\hline 妙法寺 (神巨市須磨区妙法寺) & 20 & 粎 80 & $\mathrm{~B}$ \\
\hline 蕦磨寺 (神戸市須磨区西須磨) & 20 & 粎120 & $\bar{B}$ \\
\hline 安㲔寺（神戸市垂水区塩屋町） & 30 & 料 150 & $\mathrm{~A}$ \\
\hline 舞子樭園（神官市垂水区舞子陵） & 11 & 約6500 & $\bar{A}$ \\
\hline 長寿院（明石市人丸町) & $90-95$ & 500前後 & $\mathrm{C}$ \\
\hline 安菨寺墓苑 (明石市鳥羽) & 15 & $300-350$ & $\mathrm{~A}$ \\
\hline
\end{tabular}

\section{3. 蒀石の転倒率と地形との関係}

\section{1 基石の転倒調査}

筆者らにより神戸市およびその周辺での墓石の転倒 調查が95年1月19日から3月4日にかけて62地点の墓地に 対して行われた 幅・奥行き $30 \mathrm{~cm}$ 程度でほぼ一定であることから, 墓石の 転倒率を調查した。調査の際には，平均的な大きさでな い墓石は除外するよう心掛けた。その後も 95 年 12 月まで に10地点の墓地に対して調查を追加した。

これら合計72地点での調査結果を表 1 に示す。調查範 囲は神戸市を中心として東は大阪府豊中市から西は兵 庫県明石市までの東西約 $50 \mathrm{~km}$ の範囲である。調查は地震 直後に行われたものだけではないために，調查結果の信 頼度は地点ごとに異なる。そこで, 表には調查結果の信 頼度を3ランクにわけて示してある。ランクAは著者ら により直接数えられた信頼度の高いもの, ランクBは墓 石の傷跡や墓地の関係者の証言から推定されたもので あるが信頼度の比較的高いもの, ランクCは信頼度のや や少るものである。

神戸市およびその周辺における墓石の転倒率の分布 を図 2 に示す。転倒率は半数以上の地点で $50 \%$ 以上の大 きな值を示している。神戸市をはじめ, 芦屋市, 西宮市, などで， $80 \%$ 以上の転倒率を示す地点が存在する。これ

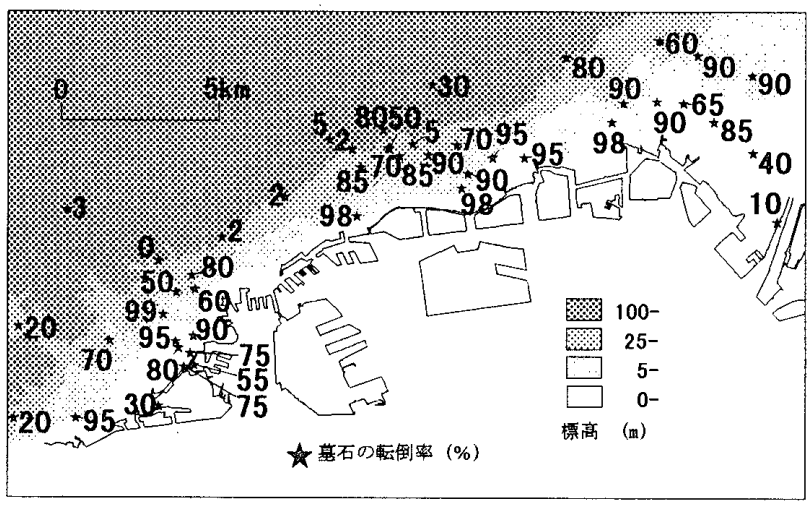

図 2 神户市およびその周辺における墓石の転倒率の分布

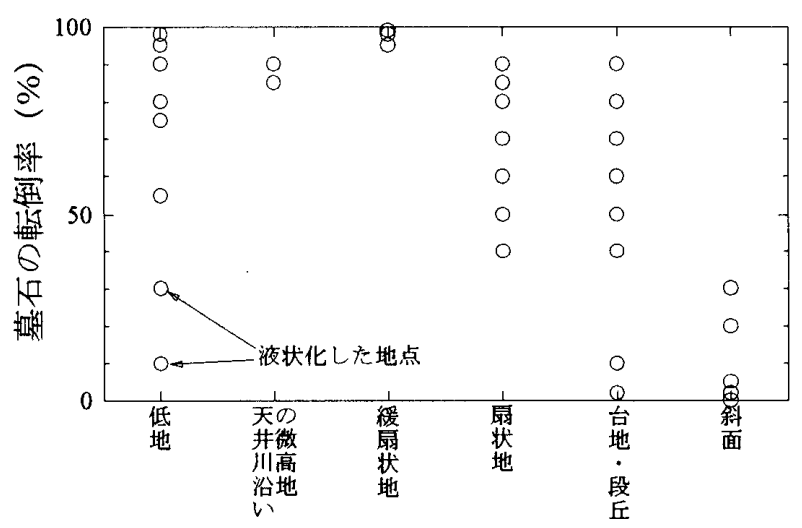

図 3 地形条件と墓石の転倒率との関係 


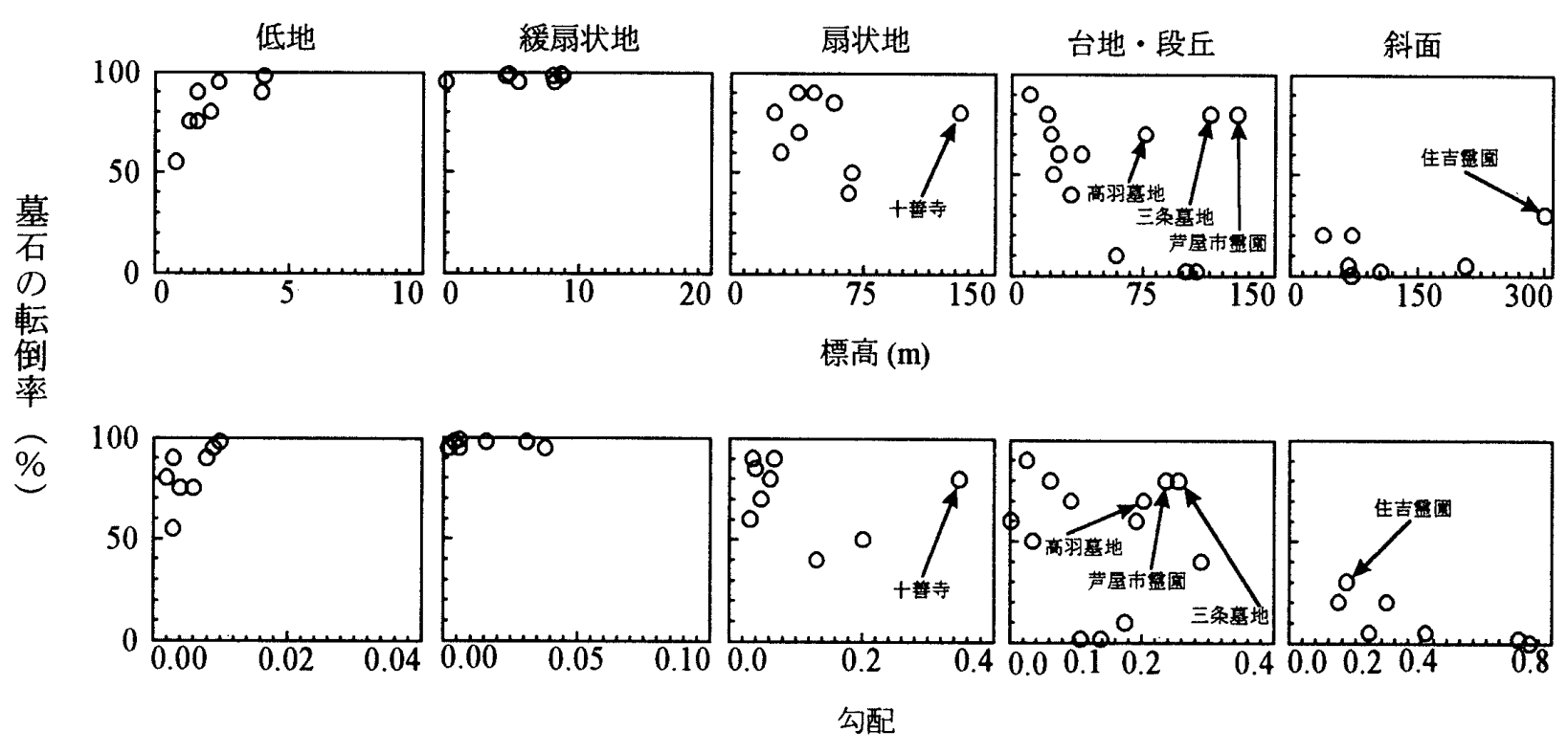

図 4 各地形条件毎の地形計測值と墓石の転倒率との関係

らの高い転倒率を示す地点は，神戸市付近においては東 北東一西南西方向に長い帯状に分布している。一方，山 地部では転倒率は急激に减少し，数\%以下の值を示して いる。

\section{2 蒀石の転倒率と地形分類の関係}

転倒率が場所により大きく変化することから，地形条 件と墓石の転倒率との関係について検討した。この地震 の強震記録の解析 ${ }^{11)}$ から，断層からの距離が $5 \mathrm{~km}$ 程度以 内では, 地震動強さはほぼ飽和しており, 距離减衰の影 響はほ湆無視できるものと考えられる．そこで，震源断 層 ${ }^{12)}$ 加 $5 \mathrm{~km}$ 以内にある地点を対象とし，墓石の転倒調 查全地点のうち49地点のデータを用いた。

図 3 は, 地形条件と墓石の転倒率の関係を示したもの である。各地形条件の並べ方は，左から右へと標高が高 くなるように配置してある。標高が高い地形条件ほど転 倒率が小さくなる傾向が認められ，斜面(山地に対応)で は転倒率30\%以下の低い值を示しており，転倒率0\%の地 点も存在する。一方，緩扇状地では転倒率 $95 \%$ 以上の非 常に高い值を示している。これは緩扇状地で被害が集中 しているこどと調和的である。

低地において転倒率は10～98\%とかなりばらついた 值を示すが，これらのうち転倒率10\%および30\%の地点 では液状化が発生しており，この 2 地点を除くと低地で の転倒率は55～98\%となる。以上より，地形条件毎に平 均的な墓石の転倒率は異なることがわかる。ただし，同 じ地形条件であっても，転倒率にはばらつきがみられる ことも読み取れる。

\section{3 募石の転倒率と地形㖕測值との関係}

同一の地形条件でも転倒率にばらつきがみられるこ とから，各地形条件毎に地形計測值と墓石の転倒率との
関係について検討をおこなった。図 4 は，地形条件毎の 地形計测值と墓石の転倒率との関係を示したものであ り，上段は標高と墓石の転倒率との関係，下段は勾配と 墓石の転倒率との関係を表している。

斜面では，大規模な造成がなされた 1 地点(住吉霊園) を除くと，標高が高いほど，勾配が大きいほど転倒率が 低くなる傾向がみられる。台地・段丘においても，芦屋 市霊園, 高羽墓地, 三条墓地の 3 地点を除くと, 地形計 測値が大きくなるにつれて転倒率は減少している。なお， これら 3 地点は大規模な造成が行われたものだったり， 崖地の上縁部に位置していたりしている。

扇状地でも， 1 地点(十善寺)を除くと，地形計測值が 大きくなるほど転倒率は減少する傾向がやや認められ る。なお，十善寺は崖地斜面に位置している。

緩扇状地では，データが標高で0.1〜9mおよび勾配で 0.002 0.04の範囲に限定され，転倒率は全地点で $95 \%$ 以 上の非常に高い值を示している。低地の場合，地形計測

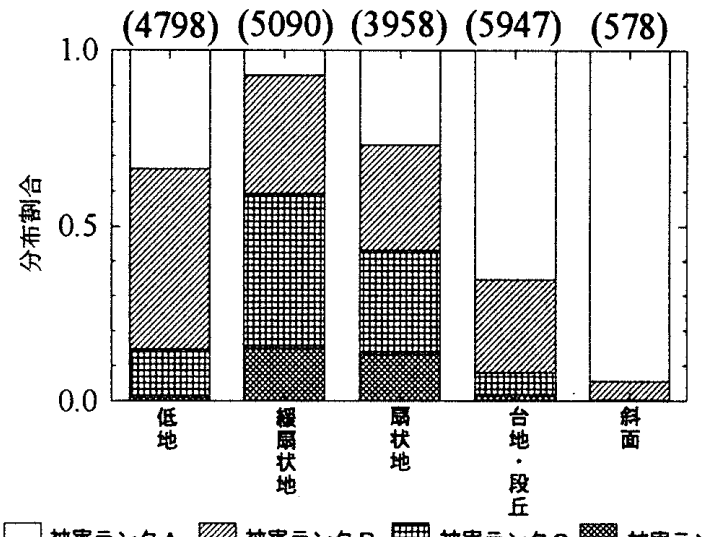

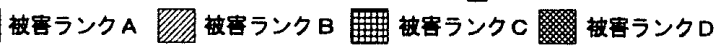

図 5 地形条件と建築物被害との関係 


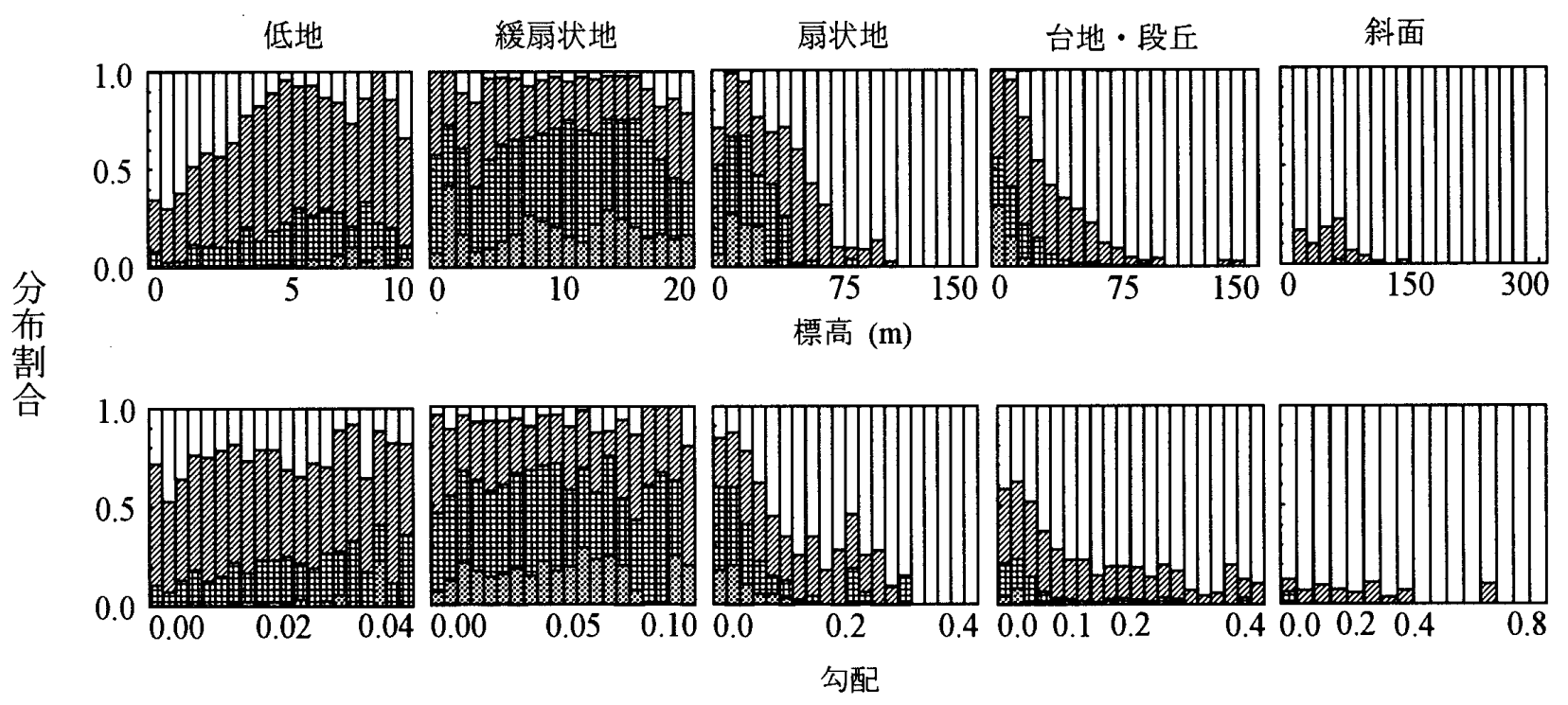

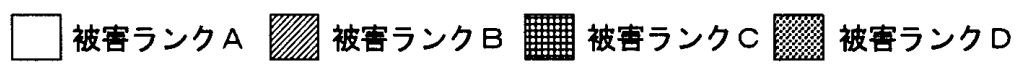

図 6 各地形条件毎の地形計測値と建築物被害との関係

值が大きくなるほど転倒率は大きくなるようにもみえ る。しかし, データが標高で $0.8 \sim 4 \mathrm{~m}$ おび勾配で 0.002 〜0.01の範囲に限られており，この範囲外での傾向を知 ることはできない。なお, 低地の液状化地点でのデータ は除いてある。

以上から, 各地形条件毎に地形計測值と墓石の転倒率 の間にある程度の相関がみられることがわかる。しかし， 墓石の転倒調查地点での地形計測值の分布が限られて いる場合があり，図4の関係を定量化することには困難 が伴う。そこで，これを補うために，より広い地形計測 值の範团でデータが分布する建築物被害と地形条件と の関係について検討することとした。

\section{4 建築物被害と地形の関係}

建築物被害分布として, 中央開発による建築物被害々 ップ13)を使用した。この被害調查は, 木造家屋および鉄 筋コンクリート建屋(5 10階建 R C 造)を対象として, 街 区・町丁ブロック当たりの倒壊率の概数を算出して, 被 害のランク分けを行ったものである。本研究では, 壁に 割れ目が入る，木造住宅の倒壊率30\%以下，木造住宅の 倒壊率 30\%以上，木造住宅の倒壊率50\%以上ないし鉄筋 コンクリート造建物の被害多数の各被害ランクを，それ ぞれ，被害ランク A, B , C,D と呼ぶことにする。

図 5 に, 各地形条件における被害ランクの分布割合を 示す。なお，検討には，墓石のデータの場合と同様に， 震源断層から $5 \mathrm{~km}$ 以内の被害データのみを用いた。図中 の()内の数字は, 各地形条件の被災メッシュ数(被害ラン ク A, B, C,Dのいずれかに該当したメッシュ数の総数) を示している。墓石の転倒率と同様に, 被害恃, 斜面 で小さく，緩扇状地で最大となっている。
同様に，地形計測値と建築物被害との関係について， 図 6 に示す。上段は標高と建築物被害との関係を,下段 は勾配と建筑物被害との関倸を各地形条件每に示して いる。図の縦軸は, 被害ランクの分布割合を示したもの である。斜面では, 勾配との相関はあまり明確ではない ものの，標高が高くなるにつれて被害が小さくなる傾向 が認められる。台地・段丘および扇状地では, 標高が高 いほど, 勾配が大きいほど被害は瑊少している。緩扇状 地では, 標高および勾配の全範囲にわたって被害が大き い。低地では, 標高が低くなるほど, 勾配が小さくなる ほど，被害がやや減少する傾向がみられる。

以上のように, 建物の被害状況については, 地形条件 毎に地形計測值との関係がより広い地形計測值の範囲 で比較的明瞭に認められる。そこで，この傾向を利用す れば, 地形計測值が分布していない範囲におけりる地形計 測值と墓石の転倒率との関係を外挿できるものと考え られる。

\section{5 地形条件每の蓦石の転倒率と地形計測值との関係式}

前述の地形計測值と墓石の転倒率との関係基本と し, 地形計測值が分布していない範囲については, 地形 計測値と建築物被害との関係から類推して, 地形計測値 と墓石の転倒率との関保式を設定することとした。その 際に用いる地形計測值については, 勾配の方が墓石の被 害との相関がやや高いようにみえるので, 勾配を使用す ることにした。勾配の対数と墓石の転倒率の関係を線形 的に表現できると考え, 図 7 に示す関係を, 斜面, 台地・ 段丘，扇状地，緩扇状地，低地に対して設定した。

斜面については, 勾配と墓石の転倒率との関係におい て，勾配が 0.15 程度以上で勾配が大きくなるほど転倒率 
は小さくなっており，建築物被害では，小さな勾配では 被害状況がほぼ同程度である。そこで，勾配0.15以下で は転倒率は $25 \%$ で一定とし，それ以上の勾配では，勾配 0.7 で転倒率が $0 \%$ となる一次式を設定した。

台地・段丘の場合も，墓石の転倒率は勾配が大きくな るほど減少する傾向が認められ，建築物被害をみると， 勾配0.04以下では，被害状況がほぼ同程度である。そこ で，勾配0.04以下では転倒率 $80 \%$ として，それ以上の勾 配では，勾配0.6で転倒率 $0 \%$ となる一次式を設定した。

扇状地でも，ばらつきはあるが，勾配が大きくなるに つれて墓石の転倒率が小さくなる傾向がやや認められ， 建築物被害では，勾配0.04以下ではほぼ同程度の被害状 況である。そこで，勾配0.04以下では転倒率 $85 \%$ で一定 とし，それ以上の勾配では，勾配0.6で転倒率 $0 \%$ となる 一次式を設定した。

緩局状地では, 墓石の転倒率および建築物被害状況が ほぼ一定であることから，転倒率は95\%で勾配によらず 一定とした。低地の場合，勾配が大きくなるにつれて転 倒率は大きくなるが，勾配 0.01 以上では，建築物の被害 状況がほほ同程度である。そこで，勾配0.01以上では勾 配によらず転倒率は90\%で一定とし，それ以下の勾配で は，勾配0.001で転倒率 $75 \%$ となる一次式を設定した。な お，天井川沿いの微高地には 3 地点しか該当しなかった が，転倒率は85-90\%といずれも高い值を示しているた め, 転倒率は一律 $90 \%$ とした。

図7に示した関係を見ると, 斜面, 台地・段丘, 扇状 地, 緩扇状地の順に転倒率は大きくなっており,この順 で地盤が摇れやすくなることを示唆している。このこと 注既往の地形と地盤の増幅率の関係と調和的であり ${ }^{14)}$, 比較的浅い地盤構造の影響が反映されているものと考 えられる。また, 勾配が大きくなると転倒率が小さくな ることも, 勾配が大きくなるほど堆積層が薄くなると考 えれば説明できる。しかし, 低地に比べ緩扇状地で転倒

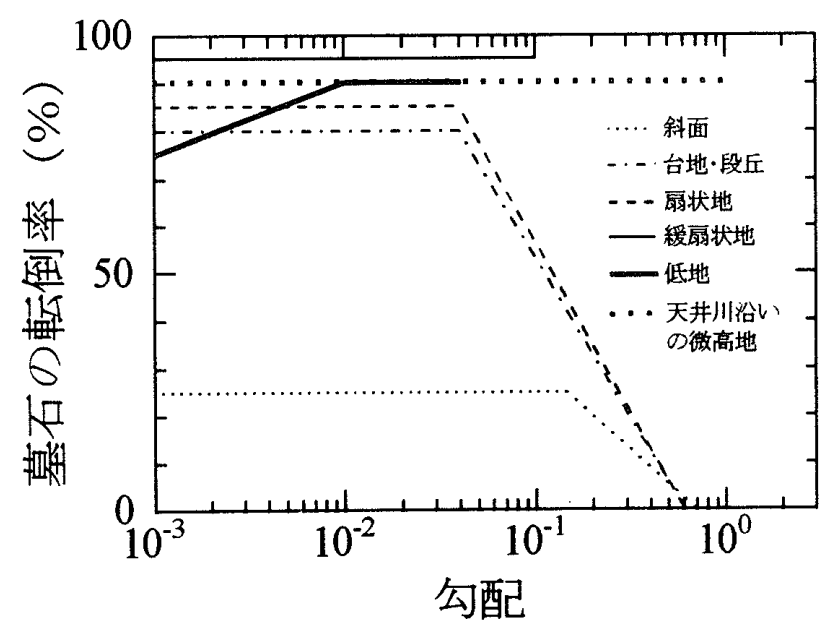

図 7 各地形条件の勾配と墓石の転倒率との関係式
率が大きいことや低地では勾配が非常に小さくなると 転倒率が減少する傾向がみられることは, 既往の地形と 地盤の增幅率の関係と調和的ではない" ${ }^{14)}$ 。

緩扇状地は海岸線から低地をはさんである程度離れ た場所に位置している。また，一般に海岸線に近づくに つれて勾配は小さくなる。したがって，低地に比べ緩扇 状地で転倒率が大きいことや，低地では勾配が非常に小 さくなると転倒率が减少する傾向にあることは, 海岸線 からある程度離れた地域で転倒率が大きいことを示し ているものである。

震度VIIの帯が発生した原因として, 深い地盤の不整形 性の影響であることが指摘されている。例えば，三宮を 南北に横切る地盤断面での地震動シミュレーション結 果 ${ }^{15}$ によると，地盤が急激に浅くなる山側端部から水平 に伝播する回折波と堆積層を鉛直に上昇してくる実体 波が重なり合うために，旧海岸線から 動の振幅が増大する。

このことは, 海岸線からある程度離れた地域で転倒率 が大きいことに対応し，低地に比べ緩扇状地で転倒率が 大きいことや，低地では勾配が非常に小さくなると転倒 率が減少寸る傾向にあることを説明するものである。し たがって，図7に示した関係は，浅い地盤構造および梁 い地盤構造の影響によって定性的には説明できるもの であり，対象地域では妥当な結果を与えるものと判断で きる。

\section{4.神戸市域での镸大速度分布の推定}

各地形条件に対して設定した地形計測值と墓石の転 倒率の関係式により，震源付近での墓石の転倒率の分布 を得ることができる。こうして得られた各地での基石の 転倒率を地震動強さに換算するために, 岡田・鏡味(1991) によるバルナラビリティ関数 ${ }^{16)}$ を参考として，換算式を

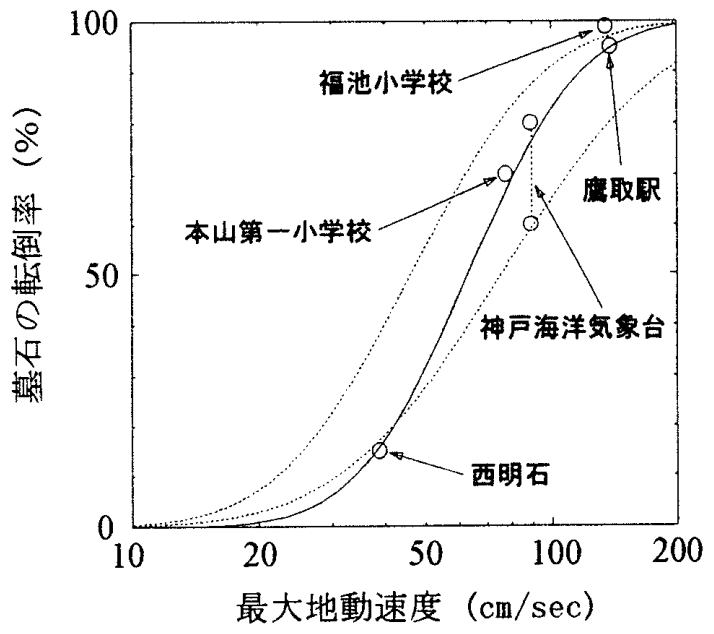

図 8 最大地動速度と墓石の転倒率との関係 
表 2 強震観測点之付近の墓地

\begin{tabular}{|c|c|c|c|c|c|}
\hline 強震観測点 & 地形条件 & 最大速度 & 付近の墓地 & 地形条件 & 転倒率 \\
\hline 鷹取駅 & 緩扇状地 & $138 \mathrm{~cm} / \mathrm{s}$ & 鷹取墓地 & 緩扇状地 & $95 \%$ \\
\hline \multirow{2}{*}{ 神戸海洋気象台 } & \multirow[t]{2}{*}{ 台地・段丘 } & \multirow[t]{2}{*}{$90 \mathrm{~cm} / \mathrm{s}$} & 馬場墓地 & 台地・段丘 & 7 \\
\hline & & & 女養寺 & 台地・段丘 & $60 \%$ \\
\hline 西明石 & 台地・段丘 & $39 \mathrm{~cm} / \mathrm{s}$ & 安養寺墓園 & 台地・段丘 & $15 \%$ \\
\hline 本山第一小学校 & 台地・段丘 & $77 \mathrm{~cm} / \mathrm{s}$ & 野崎墓地 & 扇状地 & 709 \\
\hline 福池小学校 & 緩扇状地 & $34 \mathrm{~cm}$ & 西青木墓地 & 緩扇状地 & $\bar{a}$ \\
\hline
\end{tabular}

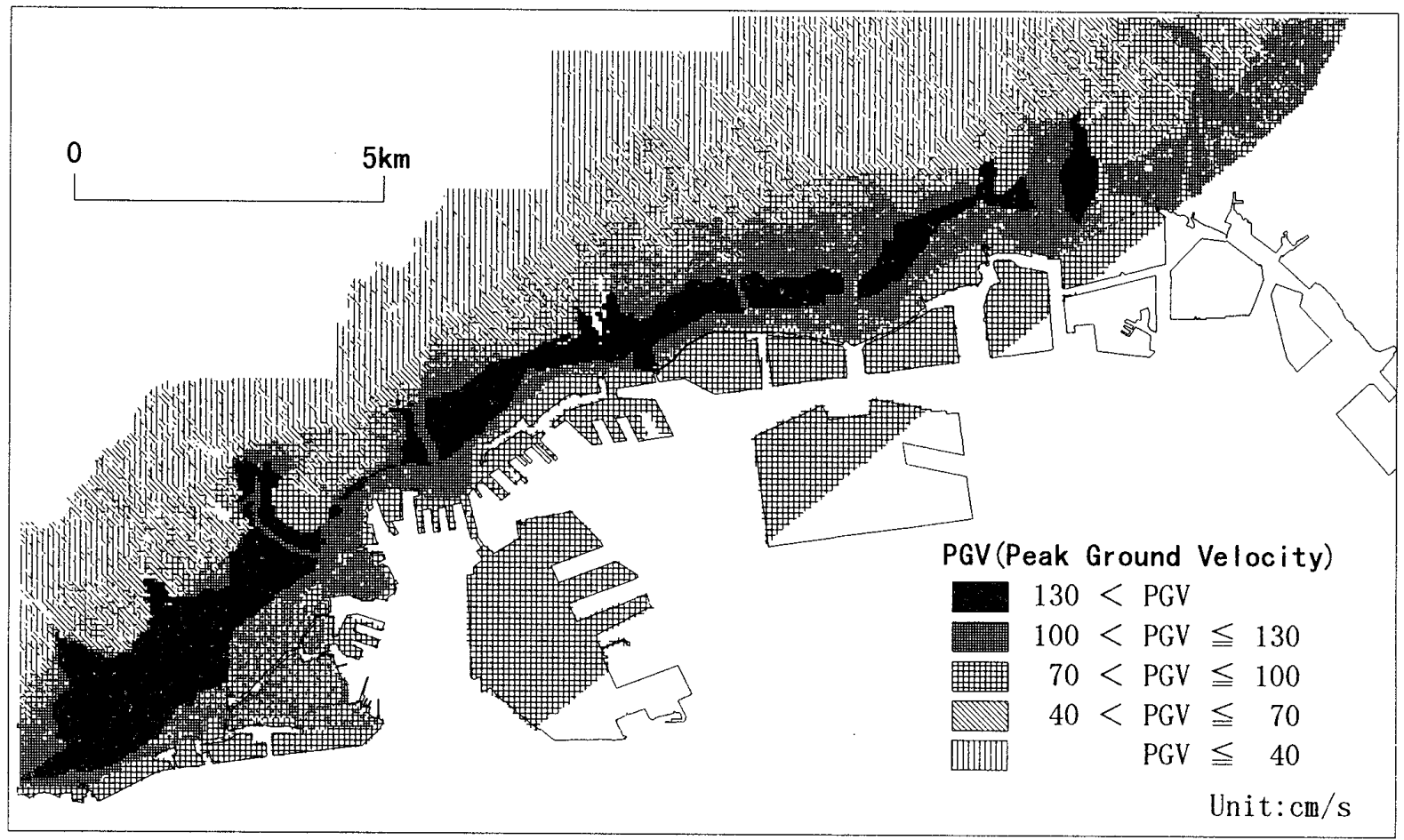

図 9 神戸市およびその周辺での最大速度分布

設定することとした。彼らは, 震度 I と墓石の転倒率 $V_{r}$ の関係を(2)式の正規分布関数で示している。

$V_{r}=1 /(\sqrt{2 \pi} \cdot 0.47) \cdot \int_{0}^{1} \exp \left[-\left(I^{\prime}-5.63\right)^{2} /\left(2 \cdot(0.47)^{2}\right)\right] \cdot d I$

この式によれば，震度5.5(震度 VとVIの境界)で転倒率は $50 \%$ 弱となる。

墓石のような単体が単純な回転運動で転倒すると考 えると，最大速度振幅が転倒の条件を与えることが指摘 されている では最大地動速度と相関が高いことも指摘されている ${ }^{18)}$ そこで，震度と最大地動速度との関係式 ${ }^{18)}$ 用いて，(2) 式から最大地動速度亡転倒率の関係を求めてみると, 図 8 の点線の関係が得られる。線が 2 本あるのは, 震度と 最大地動速度の関係にある幅があるためである。

今回の地震で得られた強震記録 ${ }^{19)}$. ${ }^{20}$ および余震観测 記録から推定された本震地動 ${ }^{21)}$ 最大速度值と墓石の転 倒率との関係を図 8 にプロットすると，白丸のようにな る。これらは 2 本の破線の間に分布している。表 2 に用 いた地震観測点とその付近の慕地でのデータの一覧を
示す。

最小 2 乗法により、これらのデータから, 墓石の転倒 率を最大速度の対数の正規分布関数にフィッティング させた。得られた結果は(3)式であり，図に実線で示す。 最大地動速度 $34 \mathrm{~cm} / \mathrm{s}, 63 \mathrm{~cm} / \mathrm{s}, 118 \mathrm{~cm} / \mathrm{s}$ がそれぞれ転倒率 $10 \% ， 50 \% ， 90 \%$ 対応している。

$V_{r}=1 /(\sqrt{2 \pi} \cdot 0.21) \cdot \int_{0}^{\log V} \exp \left[-\left(\log V^{\cdot}-\log (63)\right)^{2} /\left(2 \cdot(0.21)^{2}\right)\right] \cdot d\left(\log V^{\prime}\right)$

以上より, 地形条件毎の地形計測值之墓石の転倒率之 の関係式から墓石の転倒率の分布を求め，これに上述の 墓石の転倒率と最大地動速度の関係を用いて最大地動 速度分布を推定した。なお，墓石の転倒調査データがな い埋立地については，ポートアイランドや東神戸大橋で の観測值 ${ }^{19)}$ を参考にして，一律 $90 \mathrm{~cm} / \mathrm{s}$ とした。自然堤防 や砂州・砂堆では，地盤の堌幅度が三角州性低地と扇状 地の中間の値をとるここ ${ }^{14)}$ から, 低地と扇状地で推定さ れる最大地動速度の中間をとって，100 $\mathrm{cm} / \mathrm{s}$ とした。

推定された神戸市域での最大速度分布を図 9 に示す。 
山地部では最大速度 $50 \mathrm{~cm} / \mathrm{s}$ 以下の值を示し, 海側に向か うほど最大速度は大きくなり, 被害の甚大だった震災の 帯では最大速度 $140 \mathrm{~cm} / \mathrm{s}$ 程度と推定される。さらに海側 一向かうと, 最大速度は次第に小さくなり，埋立地ある いは低地の海岸付近では $100 \mathrm{~cm} / \mathrm{s}$ 以下となる。

気象庁発表による震度 7 の地域と推定された最大速 度分布とを比較すると, 神戸市長田区から芦屋市西部に かけての地域では, 最大速度值 $100 \mathrm{~cm} / \mathrm{s}$ 強以上の地域と 震度 7 の地域が概ね対応している。しかし, 芦屋市東部 から西宮市西部の震度 7 の地域では，最大速度值は 80 $100 \mathrm{~cm} / \mathrm{s}$ 程度とやや小さい。ただし，前述の建築物被害 マップ ${ }^{13)}$ をると, 芦屋市東部から西宮市西部の震度 7 の地域での被害は, 他の震度 7 の地域に比べて小さく, 推定された最大速度分布と調和的である。これらのこと から, 本手法により推定された最大速度分布は, 震度 7 の分布や建築物被害分布を大局的には説明しているも のと考えられる。

\section{5. 結論}

神戸市およびその周辺での墓石の転倒調查結果に基 づいて, 兵庫県南部地震での墓石の転倒率と地形条件お よび地形計測値の関係を定量的に評価し，地形条件およ び地形計測值と墓石の転倒率との関係を定めた。さらに, 墓石の転倒率と最大地動速度の関係式を設定して, 最大 速度分布を推定した。その結果, 以下の結論を得た。

1) 地形条件と墓石の転倒率との関係を検討した結果, 緩扇状地において最も被害が大きく, 標高が高い地 形条件ほど被害は堿少する傾向があることがわか った。

2) 地形計測值と墓石の転倒率との関係を検討した結 果, 斜面, 台地・段丘, 扇状地では標高および勾配 が大きくなるほど被害は小さくなり, 緩扇状地では 地形計測值の全範囲にわたって被害が大きく, 低地 では標高および勾配が大きくなるにつれて被害が 大きくなる傾向が認められた。

3) 推定された最大速度值は, 䋸扇状地およびその周辺 において $100 \mathrm{~cm} / \mathrm{s}$ を越え, それよりも山側では急激 に, 海側ではゆるやかに減少し, 震度 7 の分布や建 築物の被害分布と調和的な分布が得られた。

\section{参考文軼}

1) 大森房吉 : 明治24年10月28日泿尾地震に関する調査, 震災予 防調查会報告，第28号，pp.79-95，1899.

2）土田整・他 3 名: 各種地盤における平均応答スペクトル, 港 湾技研報告, Vol.12, No.4, pp.171-199, 1973.

3) 翠川三郎・松岡昌志・作川孝一：1987年千葉県東方沖地震の 最大加速度・最大速度にみられる地盤特性の評価, 日本建築 学会桡造系論文報告集, 第442号, pp.71-78, 1992.

4) 石川浩次・等口昭二・小野諭 : 神戸市街地の帯状被害と地盤, 土と基礎, Vol.44, No.2, pp.38-41, 1996.

5) 棣塚昌文・大和田清隆：阪神・淡路大震災における家屋被害 と原地形, シンポジウム「阪神・淡路大震災と地質噮境」論 文集, pp.173-179, 1995.

6) 関口辰夫 - 他 4 名 : 兵庫県南部地霞の災害現況図と地形特性 について, 11995年1月17日兵庫県南部地震調查速報会」記録, pp.53-54, 1995.

7) 島博保・奥園誠之・今村遼平：土木技術者のための現地踏查， 鹿島出版会, pp.45-50, 1982

8）清水靖夫 : 明治前期 - 昭和前期 神戸都市地図, 柏書房, 1995.

9) 野上道男: 細密DEMの紹介と流域地形計測, 地理学評論, Vol.68 (Ser.A), No.7, pp.467, 1995.

10) 藤本一雄・他3名: 1995年兵庫県南部地震の際の墓石の転倒調 查その 1 意石の転倒率の分布および地形条件との関係， 日本建筑学会大会学術講演梗概集, pp.101-102, 1995.

11) Midorikawa,S. et al. : Attenuation of Peak Horizontal Acceleration and Velocity Observed during Recent Large Earthquakes in Japan, Proceedings of the International Workshop on Site Response, Vol.2, pp.201-210, 1996.

12) Sekiguchi,H. et al. : Minute Locationing of Fault Planes and Source Process of the 1995 Hyogo-ken Nanbu(Kobe),Japan,Earthquake from the Waveform Inversion of Strong Ground Motion, Submitted to J.Phys.Earth., 1995.

13）中央開発株式会社：1995年兵庫県南部地震阪神大震災災害調 查報告書, 1995 .

14）松岡昌志・翠川三郎：国土数值情報を利用した地盤の平均 S 波速度の推定, 日本建築学会構造系論文集, No.443, pp.65-71, 1993.

15）林康祐・川瀬博：1995年兵庫県南部地震における神戸市中央 区の地震動評価, 日本建築学会構造系論文集, No.481, pp.37-46, 1996.

16）岡田成幸・鏡味洋史: 震度による地震被害采統評価のための バルナラビリティ関数群の構成, 地震 2, Vol.44, pp.93-108, 1991.

17）石山祐二・山口修由：地震動による物体の転倒に関する研究 (転倒条件の検討と提案)，日本建築学会大会学術講演梗概 集, pp.825-826, 1981.

18) 翠川三郎・福岡知久: 気象庁震度階と地震動強さの物理量と の関係, 地震2, Vol.41, pp.223-233, 1988

19）日本建築学会：1995年兵庫県南部地震強露記録资料集, 1996.

20) 香川敬生 : 平成7年兵庫県南部地震における関西地震観測研究 協議会の観測記録についての考察, 第14回若手地震工学研究 者の会セミナー 講演梗概集, pp.111-121， 1995.

21）川瀨博・他 3 名 : 余震観測記録に基づく兵庫県南部地震時の神 戸市東灘区に扔订る本霞地動の推定, 日本建築学会楧造系論 文集, No.476, pp.103-112, 1995. 